\title{
ENQUANTO VISLUMBRO A TESE, SINTO SAUDADES...
}

Adriana Claudia Martins Fighera é professora de Língua Inglesa, Mestre em Letras e estudante de Doutorado em Educação.

E-mail: teacheradrianacm@hotmail.com

Sinto saudades... Saudades de sonhar dormindo...

De com os olhos fechados adormecer...

Então, vou me iludindo para ver...

Vejo uma Casa.

Construo um parágrafo.

Planejo a concordância. Pinto um pré-texto,

Penso...

Procuro por pássaros cantarolando, não os vejo na noite que é escura, não turva.

Construo.

Começo pela fundação, bate-estacas, sapatas, bases sólidas, firmes: é uma Casa.

Um texto.

Então, padeço... E face ao compromisso na construção da argumentação, volto-me para

a Casa.

Reconheço-a no carrinho de mão, no prumo, no nível, na caixa de brita, na betoneira...

(não é assim que dizes, mas já aprendi a reconhecer teu talento).

Para tantas belas Casas, acordaste muito cedo, disposto à feitura da obra.

$\mathrm{Na}$ argamassa investiste tijolos que empilhados se alinhavam, outro e mais outro, no intervalo do tempo...

Testemunho a parede sustentar o objetivo de um renomado pedreiro.

Vislumbro a Casa, enquanto não há discussão, conclusão em Tese!

Volto-me ao texto e acrescento cimento, areia, um piso bruto que se faz verbo, quase

frase na enigmática Enciclopédia de capa azul.

Há! Que saudades que tenho de sonhar dormindo...

E, de olhar bem no alto da estante de madeira, de frente para a porta de nossa velha casa, lá na sala...

Foi em uma noite escura como essa, com os olhos bem abertos que a planta arquitetônica começou...

Levantei não tão depressa, com passos precisos e leves...

Fui para o outro lado da parede de meu antigo quarto e encarei a estante.

Lá estava ela. Peguei a cadeira da sala de jantar...

Já lá em cima desta e perto daquela passei a mãozinha de menina naqueles livros lindos, quase estátuas raras a adorar.

Ouvi meu coração cantando: - Abra! Abra! Ninguém vai acordar! 
Conto-as (já sei contar).

- Dez... (sussurro para ninguém acordar).

Como seriam por dentro...

Têm desenhos coloridos? O que são essas letras que começam com $A$...

Meu nome?

Sinto o cheiro da poeira que não visualizo na noite, não limpo, mal posso evitar o que sinto!

Volto para a minha cama com aqueles ainda seis anos de idade e um outro sonho para se sonhar...

Saudades!

Adormeço e sonho.

E sonho dormindo, sonho com a Casa, com meu Pai!

Sinto saudades...

Saudades de sonhar dormindo...

De não me iludir, mas construir em...

Tese. 